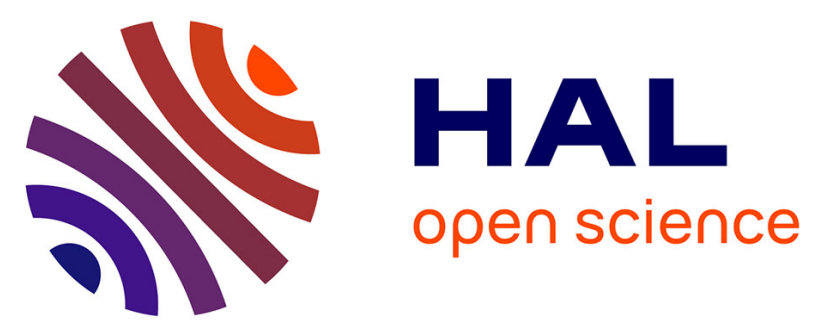

\title{
Efficient Access to Arylated Aza-ullazines by Regioselective Functionalization of their pyridine ring by H-Li exchange and Electrophilic Substitution.
} Dhuaou Ibrahim, Pascal Boulet, Philippe Gros, Philippe Pierrat

\section{- To cite this version:}

Dhuaou Ibrahim, Pascal Boulet, Philippe Gros, Philippe Pierrat. Efficient Access to Arylated Aza-ullazines by Regioselective Functionalization of their pyridine ring by H-Li exchange and Electrophilic Substitution.. European Journal of Organic Chemistry, 2021, 2021 (22), pp.3331-3339. 10.1002/ejoc.202100333 . hal-03246746

\author{
HAL Id: hal-03246746 \\ https://hal.science/hal-03246746
}

Submitted on 5 Oct 2021

HAL is a multi-disciplinary open access archive for the deposit and dissemination of scientific research documents, whether they are published or not. The documents may come from teaching and research institutions in France or abroad, or from public or private research centers.
L'archive ouverte pluridisciplinaire HAL, est destinée au dépôt et à la diffusion de documents scientifiques de niveau recherche, publiés ou non, émanant des établissements d'enseignement et de recherche français ou étrangers, des laboratoires publics ou privés. 


\title{
Efficient Access to Arylated Aza-ullazines by Regioselective Functionalization of their pyridine ring by $\mathrm{H}$-Li exchange and Electrophilic Substitution.
}

\author{
Dhuaou Ibrahim,[a] Dr. Pascal Boulet,[b] Dr. Philippe C. Gros,[c] Dr. Philippe Pierrat*[a]
}

[a] Université de Lorraine, CNRS, L2CM, F-57000 Metz, France

E-mail: philippe.pierrat@univ-lorraine.fr, Laboratory homepage : http://www.l2cm.univlorraine.fr/l2cm

[b] Institut Jean Lamour, UMR 7198 CNRS- Université de Lorraine, Campus Artem, 2 allée André Guinier, BP 50840, 54011 Nancy Cedex, France

[c] Université de Lorraine, CNRS, L2CM, F-54000 Nancy, France

Supporting information for this article is given via a link at the end of the document.((Please delete this text if not appropriate))

Abstract: The regioselective functionalization of aza-ullazines has been successfully realized for the first time by either metalation using BuLi-containing aggregates (BuLi-LiDMAE) or electrophilic substitution. Mono and di-bromo-derivatives were obtained in good to excellent yields and further successfully converted into aryl and alkynyl azaullazine derivatives via Suzuki and Sonogashira crosscoupling reactions.

Introduction

Ullazine is a unique planar nitrogen-containing polycyclic aromatic hydrocarbon (PAH) with $16 \pi$ electron system, which holds great promise in organic functional materials such as polycyclic heteroaromatic arenes,[1,2] dye-sensitized solar cells [3-7] and organic field-effect transistors (OFET).[8-10] Ullazine has been first synthesized by Balli and Zeller in 1983.[11] From these pioneering works, this fused heterocycle has been the subject of many reports depicting various chemical routes such as using organochromium derivatives,[12] mild Friedel-Craft intramolecular arylation reactions,[13] double cyclization/hydride shift sequence,[6] light-mediated[14] and Pd-catalyzed[15] two-fold annulation of $\mathrm{N}$-arylpyrroles and by 1,3-dipolar cycloaddition of azomethine ylides with various alkynes.[16,17] Very recently, Wang et al. reported on a $\mathrm{Pd}$-catalyzed double annulation reaction allowing to prepare dibenzo[d,k]ullazines from aryne precursors.[18]

More recently, the first synthesis of 6-aza-ullazines derivatives was reported by Boldt et al. through a Brønsted acid mediated annulation involving p-toluenesulfonic acid.[19] Concomitantly, our research group described the mono- and bisannulation of dialkynyl- $\mathrm{N}$-(het)arylpyrroles promoted by $\mathrm{InCl} 3$ under microwave-assisted heating.[20] Along both reports, it was shown that the introduction of the additional nitrogen atom at position 6 within the ullazine backbone (i.e. aza-ullazine) did not induce significant electronic changes in comparison with the parent ullazine core. Indeed, azaullazine and ullazine display similar absorption and emission properties. Aside from the identical photophysical features of these heterocycles, the presence of an additional nitrogen atom at the peripheral position may facilitate a regioselective functionalization of this $\mathrm{N}$-heterocycle to enable rational tuning of its optoelectronic properties. In that context, we studied the functionalization of this new pyridine-like heterocycle using metalation and electrophilic aromatic substitution reactions. We showed that we 
could promote an effective $\mathrm{H}$ - $\mathrm{Li}$ exchange at the alpha-position of the peripheral nitrogen atom allowing the introduction of various valuable halogen atoms. Moreover, while previous works on electrophilic substitutions on ullazine derivatives showed the formation of a mixture of 2 main isomers which separation is reported to be tedious (scheme 1, upper part),[6] electrophilic substitution on 6aza-ullazine occurred regioselectively. We thus developed, for the first time, efficient chemical sequences to functionalize azaullazine heterocycle, based on $\mathrm{N}$-bromosuccinimide electrophilic substitution followed by $\mathrm{Pd}$-based cross-coupling reactions allowing to prepare mono- and bis-arylated aza-ullazine derivatives in good yields.
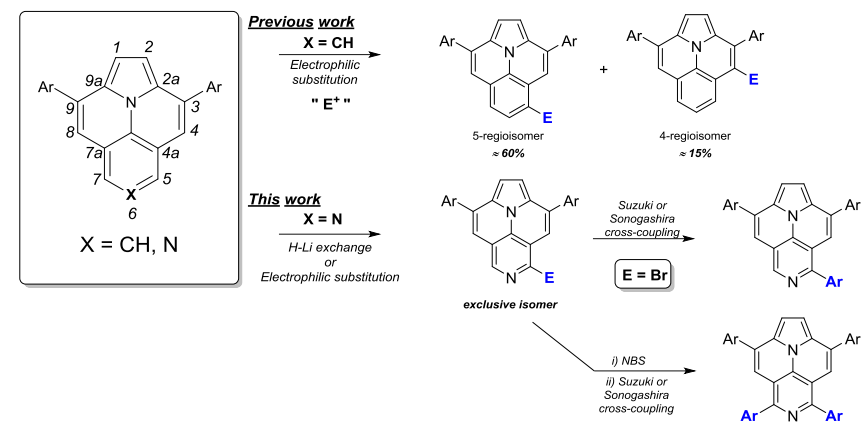

Scheme 1. General chemical routes toward functionalized ullazine-based derivatives. NBS $=\mathrm{N}-$ bromosuccinimide. Numbering on the left-hand side is appropriated only when $\mathrm{X}=\mathrm{CH}$.

\section{Results and Discussion}

Starting material 4 was obtained in 4 steps ( 3 of them performed under microwave irradiation) starting from commercially available 4-aminopyridine (scheme 2). Briefly, a double bromination at positions 3 and 5 is promoted using $\mathrm{N}$-bromosuccinimide (NBS) followed by the formation of the pyrrolic ring using 2,5-dimethoxytetrahyrdofuran and catalytic iodine[21] to afford product 2 in $74 \%$ overall yield. Next, a two-fold Sonogashira cross-coupling reaction was performed under microwave heating with phenylacetylene to obtain product 3 in $99 \%$ yield. Finally, double annulation was performed using an excess of $\mathrm{InCl} 3$ as Lewis acid ( 3 eq.) under microwave heating at $210^{\circ} \mathrm{C}$ for 20 minutes which allows us to isolate the starting material 4 in $73 \%$ yield ( $53 \%$ over 4 steps) as pure material.

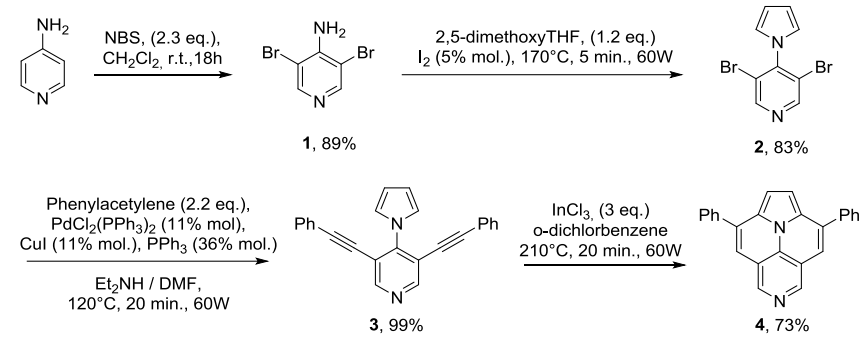

Scheme 2. Synthetic route toward starting material 4.

Over the last decades, our laboratory has developed regioselective lithiation agents of functional pyridine derivatives.[22,23] Among them, BuLi-containing aggregates BuLi-LiDMAE (LiDMAE = $\mathrm{Me} 2 \mathrm{~N}(\mathrm{CH} 2) 2 \mathrm{OLi})$ is allowing to promote $\mathrm{C}-2$ pyridine ring lithiation of various pyridine derivatives,[2427] owing to the complexation of the aggregate with the nitrogen atom of the pyridine ring. According to the chemical structure of compound 4, we thought this reagent could be valuable to promote the introduction of various functional groups in the azaullazine series through $\mathrm{H}$-Li exchange. Thus, the metalation was carried out under various conditions in toluene as solvent which is known to favor aggregate formation (Table 1). Lithiated species were first quenched with $\mathrm{C} 2 \mathrm{Cl} 6$ as electrophile solution in toluene. As shown, metalation conducted at $0^{\circ} \mathrm{C}$ led to the exclusive addition of $\mathrm{n}$ - 
buthyllithium at the $\mathrm{C} 1$ position of the naphthyridine heterocycle leading to the formation of product 5 in $60 \%$ isolated yield (entry 1). Interestingly, by lowering the metalation temperature to $-80^{\circ} \mathrm{C}$, the nucleophilic addition product was no more detected (entry 2 ). Instead, the metalation occurred with total conversion since the starting material 4 was completely consumed after quenching with the corresponding electrophile. These reaction conditions allowed us to introduce a chlorine, bromine and iodine atom at the alpha position of the naphthyridine ring and to isolate compounds $6 \mathrm{a}, 6 \mathrm{~b}$ and $6 \mathrm{c}$ in $37 \%, 46 \%$ and $43 \%$ yield, respectively. The alpha isomer is the sole detected in the crude product and no product arising from metalation of the vinyl protons was detected.

Table 1. Azaullazine metalation parameters screening. ${ }^{[a]}$

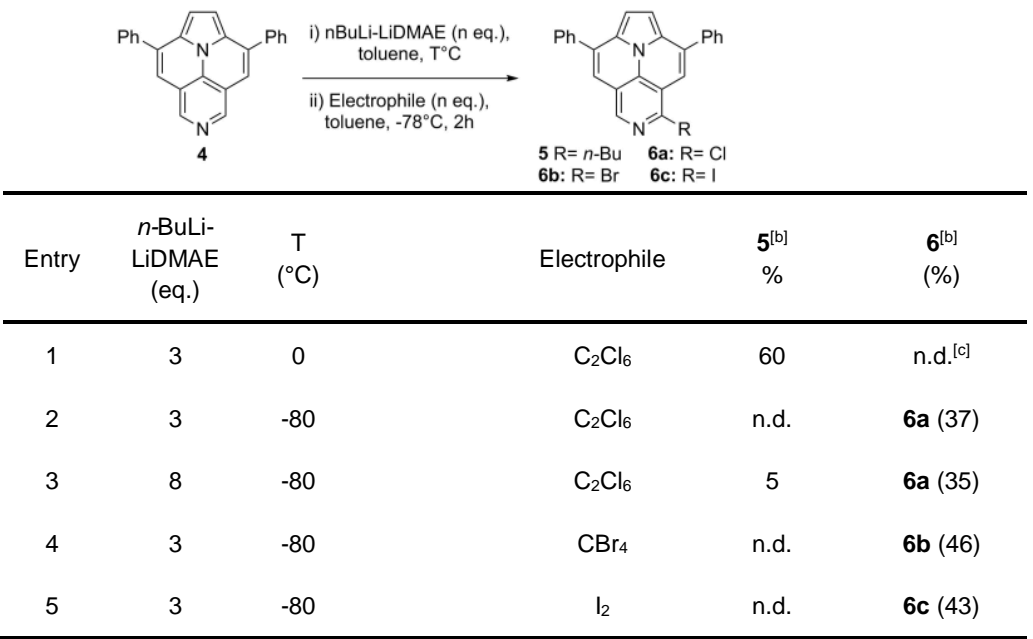

[a] All reactions were performed on $1.3 \mathrm{mmol}$ of 4 . [b] Isolated yields after column chromatography. [c] Not detected.

All attempts to improve the reaction yields remained unsuccessful. For instance, it is important to emphasize that the electrophilic halogenation must be done in non-chelating solvent such as toluene, since its replacement by THF completely hampers the halogenation step leading to the recovery of starting material 4 (data not shown). According to the deep red color of the reaction medium obtained next to the metalation step (entries 2, 4 and 5), it could be hypothesized that the carbanion formed could be highly delocalized all along the whole planar heterocyclic structure. Structures of compounds $6 a-c$ were unambiguously determined by NMR spectroscopy and mass spectrometry.

The crystallographic structures of the bromine (6b) and iodine (6c) compounds have been further solved from single crystal XRD analyses (Figure 1). As shown in Table S1, they both crystallize in the monoclinic space group P21/c (14), with a similar unit cell volume i.e. $1790 \AA 33$ and $1936 \AA 3$, respectively for $\mathrm{Br}$ and $\mathrm{I}$ at ambient temperature. The atomic positions have been found by direct method implemented in Shelx 2014.[28] 

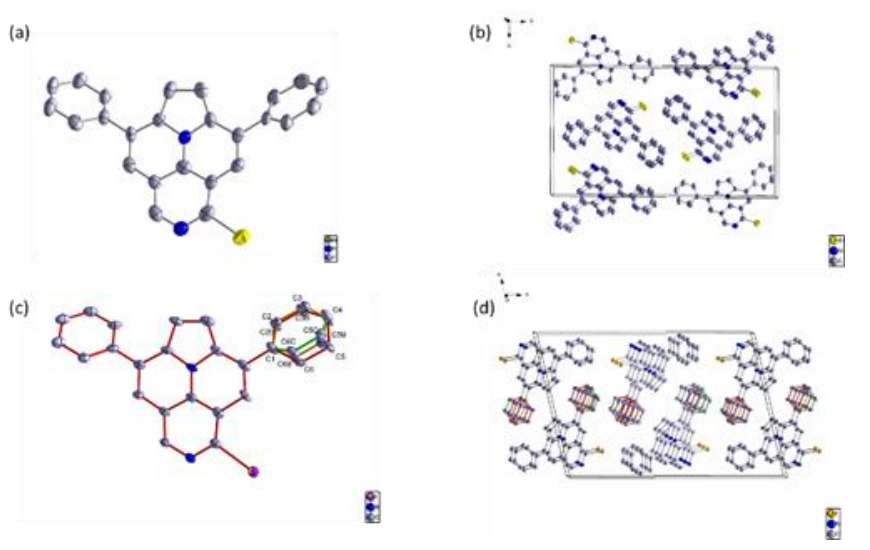

Figure 1. Crystalline structures of $6 b$ and $6 c:$ (a) asymmetric unit of $6 b$, showing the torsion angle of the phenyl groups (b) Extended crystal structure of $6 b$, (c) Asymmetric unit of $6 c$, displaying the disorder of one phenyl group (d) Extended crystal structure of $6 \mathrm{c}$. Hydrogen atoms are all omitted for clarity. Anisotropic ellipsoids are scaled to $50 \%$ probability.

In both cases the asymmetric unit is confirmed with a torsion angle between the two phenyl cycles, i.e. phenyl rings are not in the plane of the central heterocycle. The unit cells of the two structures are nevertheless different. For the bromine compound $6 b$, the unit cell dimensions are $a=3.9932(7) \AA, b$ $=28.065(5) \AA, c=16.098(3) \AA$ and $\mathrm{O}=97.033(5)^{\circ}$, with the shortest axis $a$, whereas in the case of iodine $6 c, b$ is the shortest axis with $a=16.702(2) \AA \mathrm{b}=4.6850(5) \AA, c=24.584(3) \AA$ and ( $\mathrm{a}=103.136(3)^{\circ}$. The reason of the difference between these two structures is due to steric or electronic repulsion effect between the two phenyl cycles. In the case of the bromine compounds, arrangement of the molecules among themselves does not make any constraint of the torsion angle of the phenyl, and the structural resolution did not reveal any anomaly. In the case of iodine $6 \mathrm{c}$, the $\mathrm{x}$-ray diffraction revealed a strong thermal factor for two carbon atoms from one phenyl cycle (namely C5 and C6, figure 1c). For this reason, $\mathrm{X}$-ray data were recorded at $80 \mathrm{~K}$, to minimize the thermal effect. Precise analysis of the Fourier difference leads to split this cycle in 3 different cycles. As shown in figure $1 \mathrm{c}$ the first cycle, in red, consists of the atoms $(C 1, C 2, C 3, C 4, C 5$ and $C 6)$, the second, in yellow, composed of $(C 1, C 2 B, C 3 B$, $\mathrm{C} 4, \mathrm{C} 5 \mathrm{~B}$ and $\mathrm{C} 6 \mathrm{~B}$ ) and the third in green (C1, C2 C3, C4, C5C and C6C). In all the case C1 and C4 atoms are common to each cycle, and refinement of the occupation factor reveal equal occupancy for each cycle i.e. $1 / 3$ for each. The yellow cycle is almost perpendicular to the other ones. Supplementary crystallographic data have been deposited under the number CCDC 2069795 and 2069796.

According to the modest efficiency of the metalation procedure described above, we further evaluated other functionalization approaches to introduce halogen atoms onto the heterocyclic core, halogen atoms which are highly valuable to introduce further chemical diversity. To do so, substrate 4 was subjected to aromatic electrophilic substitution using NBS as reagents. We showed that azaullazine could be converted to product $6 \mathrm{~b}$ in $77 \%$ yield at room temperature using a slight excess (1.05 eq.) of NBS in DMF as solvent. This interesting regioselectivity indicates that the azaullazine core displays a singular reactivity that has to be completely distinguished to the one of the pyridine very likely owing to complete electronic redistribution within this new $\mathrm{N}$-heterocycle. Any attempts to introduce a chlorine using $\mathrm{N}$-chlorosuccinimide were unsuccessful, while only traces amount of $6 \mathrm{c}$ were isolated in $8 \%$ yield when compound 4 was reacted with $\mathrm{N}$-iodosuccinimide in DMF at higher temperature $\left(100^{\circ} \mathrm{C}\right)$. 


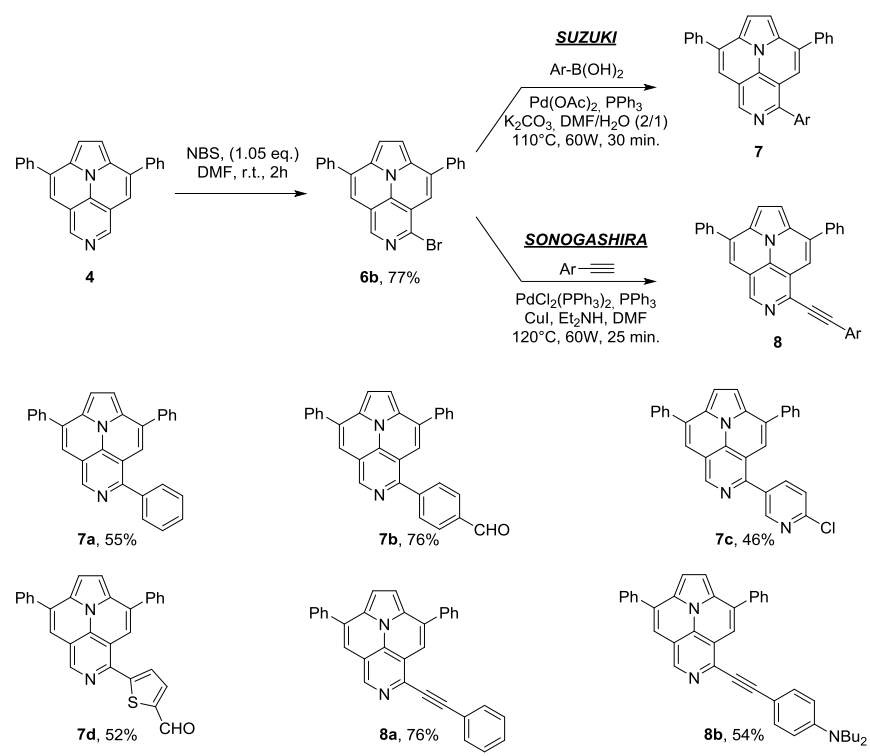

Scheme 3. Synthetic route toward brominated compound $6 \mathrm{~b}$ and subsequent Suzuki or Sonogashira cross-coupling reactions.

Compound $6 \mathrm{~b}$ was then subjected to Pd-catalyzed Sonogashira and Suzuki cross-coupling reactions on the $\mathrm{C}-\mathrm{Br}$ bond to develop a valuable synthetic route to introduce further chemical diversity at the peripheral positions. As depicted in scheme 3 , compound $6 \mathrm{~b}$ was easily transform into arylated azaullazine derivatives 7 and 8 in good yields through a microwave-assisted heating either using various (het)arylboronic acids in Suzuki cross-coupling reactions or with various alkynes in Sonogashira cross-coupling reactions.

Then, we examined the reactivity of compound $6 \mathrm{~b}$ towards a second NBS-electrophilic substitution. NMR analyses of exploratory experiments rapidly showed that a highly symmetric bis-brominated derivative was exclusively formed. Thus, reacting compound $6 \mathrm{~b}$ with a slight excess of NBS at room temperature for $18 \mathrm{~h}$ allows the formation of compound 9 in $58 \%$ isolated yield (scheme 4). Any attempts to prepare 9 from aza-ullazine 4 were unsuccessful. With compound 9 in hand, we successfully prepared symmetric bis-arylated compounds $10 \mathrm{a}-\mathrm{b}$ in good yields by a microwave-assisted two-fold Suzuki and Sonogashira cross-coupling reactions.

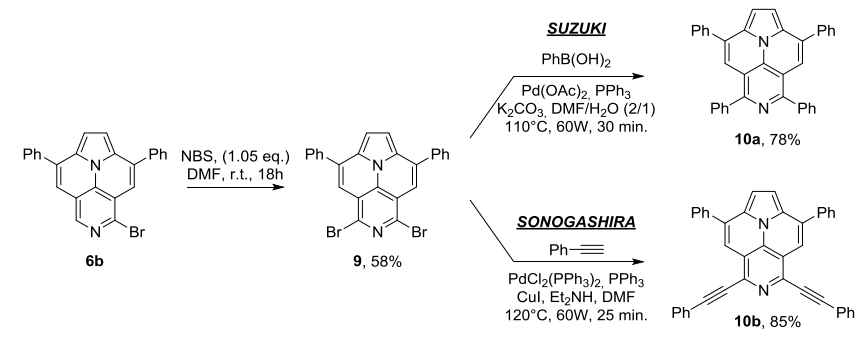

Scheme 4. Synthetic route toward compound 10a-b. 

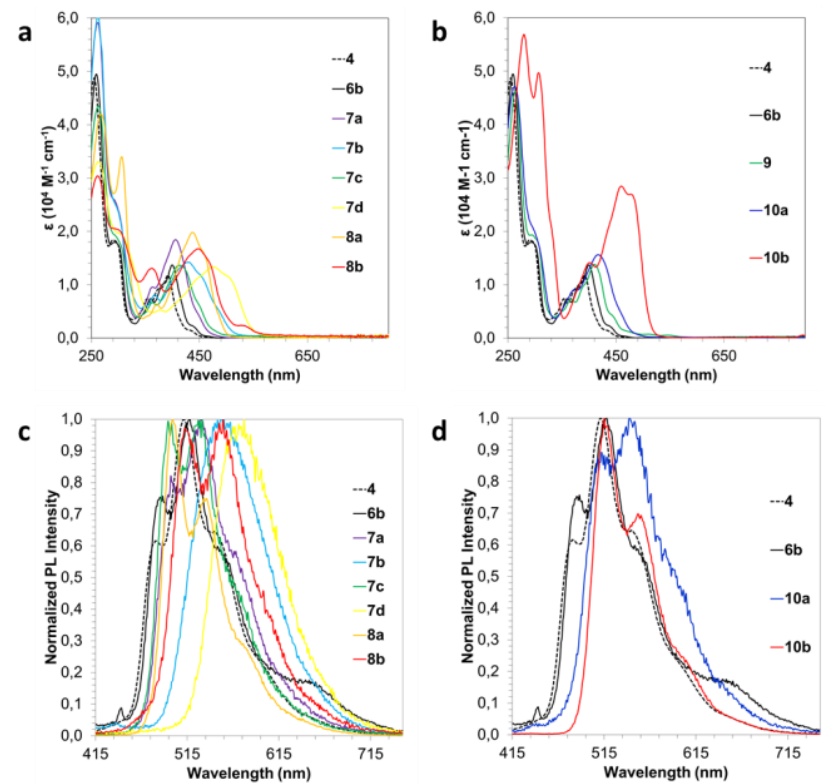

Figure 2. (a-b) UV-vis. absorption and (c-d) fluorescence spectra of compounds 4, 6b, 7a-d, 8a-b, 9 and $10 a-b$, excited at $400 \mathrm{~nm}$. All measurements were performed in air-equilibrated $10 \mu \mathrm{M}$ chloroform solutions at room temperature.

The azaullazine derivatives were studied by UV-vis and fluorescence spectroscopy and their representative photophysical data are displayed in figures $2 a-d$ and table 2 .

Table 2. Photophysical data.

\begin{tabular}{ccccc}
\hline Compd. & $\begin{array}{c}\lambda_{\text {abs }} \\
(\mathrm{nm})^{[a]}\end{array}$ & $\begin{array}{c}\varepsilon \\
\left(\mathrm{L} \cdot \mathrm{mol}^{-1} \cdot \mathrm{cm}^{-1}\right)^{[\mathrm{b}]}\end{array}$ & $\begin{array}{c}\lambda_{\mathrm{em}} \\
(\mathrm{nm})^{[\mathrm{cc}]}\end{array}$ & $\begin{array}{c}\text { Stokes Shift } \\
\left(\mathrm{cm}^{-1}\right)^{[\mathrm{d}]}\end{array}$ \\
\hline $\mathbf{4}$ & 392 & 11734 & 511 & 5941 \\
$\mathbf{6 b}$ & 400 & 13708 & 518 & 5695 \\
$\mathbf{7 a}$ & 406 & 18447 & 531 & 5798 \\
$\mathbf{7 b}$ & 430 & 14252 & 552 & 5140 \\
$\mathbf{7 c}$ & 413 & 13654 & 531 & 5381 \\
$\mathbf{7 d}$ & 475 & 13433 & 577 & 3721 \\
$\mathbf{8 a}$ & 437 & 19813 & 499 & 2843 \\
$\mathbf{8 b}$ & 448 & 16745 & 554 & 4271 \\
$\mathbf{1 0 a}$ & 417 & 15625 & 543 & 5565 \\
$\mathbf{1 0 b}$ & 459 & 28457 & 515 & 2369
\end{tabular}

[a] Maximum absorption wavelength. [b] Molar extinction coefficient. [c] Emission wavelength. [d] Stokes shift $(\mathrm{cm}-1)=[1 / \lambda$ abs $-1 / \lambda \mathrm{em}](107)$.

As depicted in figures $2 a-b$, all synthesized aza-ullazine derivatives display an intense band in the UV region with $\varepsilon$ ranging from $\approx 2-5 \times 104 \mathrm{M}-1 \mathrm{~cm}-1$. Aside from this intense usual feature, compounds display a less intense band within the visible region with maximum ranging $392-475 \mathrm{~nm}$ (Table 2). Going from starting compound 4 (?max $=392 \mathrm{~nm}$ ), the lowest-lying absorption band displays a

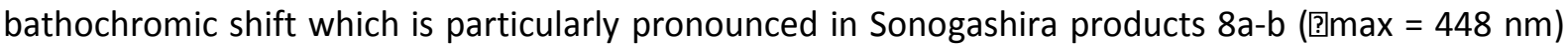


and $10 \mathrm{~b}$ ( $\ln \max =459 \mathrm{~nm}$ ) owing to the electronic participation of one or two additional alkynyl moieties, respectively. The same trend is observed by comparing compounds $7 \mathrm{a}$ and $7 \mathrm{~b}$, in which the introduction of the formyl moieties as an electron-withdrawing group induces a bathochromic shift of $24 \mathrm{~nm}$. It is also noteworthy that azaullazine 7d, bearing a 2-formylthiophene moieties, displays a lowest-lying absorption band at $475 \mathrm{~nm}$. By comparing compounds 8a and 10b, we can also notice a significant increase of the extinction coefficient resulting from the additive participation of the alkynyl moieties within the overall conjugation. Furthermore, we can observe that the low-lying absorption band of most of the compounds (apart compounds $7 \mathrm{~b}$ and $7 \mathrm{~d}$ ) reported herein displays a vibronic character (similar to azaullazine 4) suggesting a local absorption process as discussed in our previous report.[20] We studied the fluorescence properties of the azaullazine derivatives. While the brominated compound 9 was not fluorescent, other compounds $4,6 b, 7 a-d, 8 a-b$ and 10a-b display similar fluorescence feature, with fluorescence maxima ranging from 500 to $580 \mathrm{~nm}$. Emission spectra of the new compounds (apart compounds $7 b$ and $7 d$ ) are similar to azaullazine 4, displaying a structured fluorescence pattern which reflects again a local S1 $\rightarrow$ SO transition.[20] In the cases of compounds $7 \mathrm{~b}$ and $7 \mathrm{~d}$, we can notice that their emission pattern is broad indicating typically a charge transfer character, very likely resulting from the presence of the electron-withdrawing effect of the formyl moieties.

\section{Conclusion}

In summary, we report for the first time a regioselective route to functional azaullazine fused heterocycles. We showed that while metalation of azaullazine leads to the preparation of the targeted halogenated products, yields remain nevertheless modest. As an alternative, we report herein that regioselective electrophilic substitution occurred unexpectedly at the alpha position of the peripheral nitrogen atom of the naphthyridine ring. According to the efficiency of this reaction, mono and dibromo-derivatives were obtained with high regioselectivity and excellent yields and were successfully further converted to arylated aza-ullazines using Pd-assisted Sonogashira and Suzuki cross-coupling reactions. Considering the high potential of nitrogen-based polycyclic aromatic hydrocarbons particularly to be applied in electronic material science, we think the chemical approaches described herein would be interesting and useful for the related scientific community to build novel organic functional materials.

\section{Experimental Section}

All solvents were of reagent grade and, when necessary, purified and dried by standard methods. Microwave reactions were performed in a Monowave 450 apparatus (Anton Paar). All reactions were routinely checked by TLC analysis on an Alugram SIL G/UV254 (Macherey- Nagel) with spots visualized by UV light. Melting points were determined on a Koffler apparatus and were not corrected. Infrared spectra were recorded on a Thermo Scientific IR-TF Nicolet iS5 spectrometer. The $1 \mathrm{H}$ and 13C-NMR spectra were measured on an $\mathrm{AC}$ Bruker $400 \mathrm{MHz}$ spectrometer in $\mathrm{CDCl} 3$. Chemical shifts are reported in delta $(\delta)$ units, part per million $(\mathrm{ppm})$ relative to the singlet pic at $7.26 \mathrm{ppm}$ for deutoriochloroform for $1 \mathrm{H}$ NMR and relative to the center of the triplet at $77.00 \mathrm{ppm}$ for $13 \mathrm{C}$ NMR. All coupling constants (J) are given in Hz. HRMS spectra were recorded on a Bruker MICROTOF-Q ESI/QTOF spectrometer using an electrospray ionisation (ESI) process. The single crystalline analyses were performed on Bruker Kappa Apex II diffractometer equipped with a mirror monochromator and a MoK! ImS(回 = 0.71073Å). The apex 3 program package was used for the cell refinements and data reductions. The structure was solved by using direct methods and refined with the SHELXL-2014 programs.[28] Semi-empirical absorption correction (SADABS) was applied to the data.

Synthesis of the starting material 4. 
3,5-dibromo-4-aminopyridine (1). To a solution of 4-aminopyridine $(9.00 \mathrm{~g}, 96 \mathrm{mmol})$ in dichloromethane $(600 \mathrm{~mL})$ was added portionwise NBS $(39,50 \mathrm{~g}, 221 \mathrm{mmol})$ at room temperature under vigorous stirring. Once the addition was finished, the reaction mixture was stirred for $18 \mathrm{~h}$ at room temperature and, next, it was washed with aq. $0.1 \mathrm{M} \mathrm{NaOH}$ solution $(5 \times 120 \mathrm{~mL})$ and with water $(2 \times 120 \mathrm{~mL})$. The organic layer was then dried over MgSO4 and concentrated under reduced pressure. The expected compound 1 was obtained as a yellow solid (21.5 g, 89\%). $1 \mathrm{H}-\mathrm{NMR}(400 \mathrm{MHz}, \mathrm{CDCl} 3) \delta$ $=8.31(\mathrm{~s}, 2 \mathrm{H}), 5.07(\mathrm{~s}, 2 \mathrm{H})$.

3,5-dibromo-4-(1H-pyrrol-1-yl)pyridine (2). In a $30 \mathrm{~mL}$ microwave vial, a mixture of compound 1 (1.00 $\mathrm{g}, 4 \mathrm{mmol})$, 2,5-dimethoxytetrahydrofuran $(0.63 \mathrm{~g}, 4.8 \mathrm{mmol})$ and iodine $(4.80 \mathrm{mg}, 5 \mathrm{~mol} \%)$ was introduced and the reaction vessel was sealed with a Teflon cap. Microwave irradiation of $60 \mathrm{~W}$ was used, the temperature being ramped to $170{ }^{\circ} \mathrm{C}$, temperature at which the reaction was heated for 5 minutes. The reaction mixture was then allowed to reach room temperature, diluted with $\mathrm{CH} 2 \mathrm{Cl} 2(60$ $\mathrm{mL}$ ) and washed with a $0.1 \mathrm{M}$ aqueous sodium thiosulfate solution $(2 \times 50 \mathrm{~mL})$ and water $(50 \mathrm{~mL})$. The organic layer was then dried over $\mathrm{MgSO} 4$ and concentrated under reduced pressure. The residue was then purified on silica gel chromatography (cyclohexane/EtOAc, 80/20) and product 2 was obtained as a yellow solid (1.00 g, 83\%). 1H-NMR $(400 \mathrm{MHz}, \mathrm{CDCl} 3) \delta=8.77(\mathrm{~s}, 2 \mathrm{H}), 6.73(\mathrm{t}, \mathrm{J}=2.2 \mathrm{~Hz}, 2 \mathrm{H}), 6.42(\mathrm{t}$, $\mathrm{J}=2.2 \mathrm{~Hz}, 2 \mathrm{H})$.

3,5-bis(phenylethynyl)-4-(1H-pyrrol-1-yl)pyridine (3). In a dry $30 \mathrm{~mL}$ microwave vial, diethylamine (7.5 $\mathrm{mL})$ and $\mathrm{DMF}(3.0 \mathrm{~mL})$ were introduced. The solvent mixture, cooled at $0^{\circ} \mathrm{C}$ with an ice bath, was then degassed by argon bubbling for 30 minutes. Compound 2 ( $1.50 \mathrm{~g}, 5.00 \mathrm{mmol}), \mathrm{PdCl} 2(\mathrm{PPh} 3) 2(386 \mathrm{mg}$, $0.55 \mathrm{mmol})$, Cul (105 mg, $0.55 \mathrm{mmol})$, triphenylphosphine $(472 \mathrm{mg}, 1.80 \mathrm{mmol}$ ) and phenylacetylene $(1.21 \mathrm{~mL}, 11 \mathrm{mmol})$ were introduced and the reaction vessel was sealed with a Teflon cap. Microwave irradiation of $60 \mathrm{~W}$ was used, the temperature being ramped to $120^{\circ} \mathrm{C}$, temperature at which the reaction was heated for 30 minutes. The mixture was then allowed to reach room temperature, filtered through a pad of Celite, washed with dichloromethane and concentrated to dryness under reduced pressure. The residue was taken up in ethyl acetate $(200 \mathrm{~mL})$. The organic layer was washed with water $(3 \times 200 \mathrm{~mL})$ and sat. $\mathrm{NaCl}(1 \times 200 \mathrm{~mL})$, dried with $\mathrm{MgSO}$, filtered and concentrated under reduced pressure. The residue was then purified on silica gel chromatography (cyclohexane/EtOAc, 95/5) and product 3 was obtained as a yellow oil which solidified upon standing $(1.70 \mathrm{~g} ; 99 \%)$. $1 \mathrm{H}-\mathrm{NMR}(400 \mathrm{MHz}$, $\mathrm{CDCl} 3) \delta=8.75(\mathrm{~s}, 2 \mathrm{H}), 7.43-7.48(\mathrm{~m}, 4 \mathrm{H}), 7.34-7.38(\mathrm{~m}, 6 \mathrm{H}), 7.32(\mathrm{t}, \mathrm{J}=2 \mathrm{~Hz}, 2 \mathrm{H}), 6.44(\mathrm{t}, \mathrm{J}=2 \mathrm{~Hz}$, 2H). 13C-NMR (100 MHz, CDCl3) $\delta=153.1,131.8,129.2,128.6,122.3,122.2,116.3,109.8,97.0,83.3$.

5,8-Diphenylindolizino[6,5,4,3-ija][1,6]naphthyridine (4). A dry $30 \mathrm{~mL}$ microwave vial flushed with argon was charged with $3(0.75 \mathrm{~g}, 2.18 \mathrm{mmol})$ and dry o-dichlorobenzene $(15 \mathrm{~mL})$. Then InCl3 $(1.44 \mathrm{~g}$, $6.54 \mathrm{mmol}$ ) was introduced in one portion and the reaction vessel was sealed with a Teflon cap. Microwave irradiation of $60 \mathrm{~W}$ was used, the temperature being ramped to $210{ }^{\circ} \mathrm{C}$, temperature at which the reaction was heated for 20 minutes. The mixture was then allowed to reach room temperature, diluted with $\mathrm{CH} 2 \mathrm{Cl} 2(300 \mathrm{~mL})$ and filtered through a Celite pad to remove insoluble residues. Next, the filtrate was washed with a $10 \% \mathrm{NH} 4 \mathrm{OH}$ aq. solution $(2 \times 300 \mathrm{~mL})$ and with water $(300 \mathrm{~mL})$. The organic layer was dried under $\mathrm{MgSO} 4$ and concentrated under reduced pressure. The residue was purified by silica gel column chromatography (cyclohexane/EtOAc, 80/20) to afford 
compound 4 as a yellow solid $(0.54 \mathrm{~g}, 73 \%)$ with a melting point of $189-190^{\circ} \mathrm{C}$. $1 \mathrm{H}-\mathrm{NMR}(400 \mathrm{MHz}$, $\mathrm{CDCl} 3) \delta=8.78(\mathrm{~s}, 2 \mathrm{H}), 7.79(\mathrm{~m}, 4 \mathrm{H}), 7.56-7.49(\mathrm{~m}, 6 \mathrm{H}), 7.28(\mathrm{~s}, 2 \mathrm{H}), 7.18(\mathrm{~s}, 2 \mathrm{H}) .13 \mathrm{C}-\mathrm{NMR}(100 \mathrm{MHz}$, $\mathrm{CDCl} 3) \delta=139.9,138.2,135.5,135.2,129.0,128.9,128.3,127.1,120.7,116.2,108.0$.

General Procedure for Monolithiation of compound 4.

To a solution of 2-dimethylaminoethanol (DMAE) $(0.40 \mathrm{~mL}, 4 \mathrm{mmol})$ in $5 \mathrm{~mL}$ of anhydrous toluene cooled at $-5{ }^{\circ} \mathrm{C}$ was added dropwise $\mathrm{n}$-BuLi $(5 \mathrm{~mL}$ of a $1.6 \mathrm{M}$ solution in hexanes, $8 \mathrm{mmol}$ ). The temperature must be kept below $0{ }^{\circ} \mathrm{C}$. After $0.5 \mathrm{~h}$, the reaction mixture was cooled at $-78{ }^{\circ} \mathrm{C}$, and a solution of $4(0.46 \mathrm{~g}, 1.3 \mathrm{mmol})$ in $15 \mathrm{~mL}$ of anhydrous toluene was added dropwise. After $2 \mathrm{~h}$ of stirring at $-78{ }^{\circ} \mathrm{C}$, the appropriate electrophile (typically $5 \mathrm{mmol}$ ) was added dropwise in $15 \mathrm{~mL}$ of toluene to the orange solution. After $1 \mathrm{~h}$, the medium was allowed to warm at room temperature and hydrolysed at $0{ }^{\circ} \mathrm{C}$ with $40 \mathrm{~mL}$ of water. After extraction with ethyl acetate and washing with water $(2 \times 20 \mathrm{~mL})$, the combined organic phases were dried over $\mathrm{MgSO} 4$ and concentrated under reduced pressure. The expected compounds were obtained as pure materials after purification on silica gel column chromatography as outlined.

1-butyl-5,8-diphenylindolizino[6,5,4,3-ija][1,6]naphthyridine (5): This compound was formed when the metalation step was performed at $0^{\circ} \mathrm{C}$, instead of being at $-78^{\circ} \mathrm{C}$ (vide supra) and using $\mathrm{C} 2 \mathrm{Cl}(1.18$ g) as electrophile. After column chromatography (cyclohexane/EtOAc, 90:10), compound 5 was obtained as a red solid $(312 \mathrm{mg}, 60 \%)$ with a melting point of $109-110^{\circ} \mathrm{C}$. FT-IR v $(\mathrm{cm}-1)=3029,2952$, $2857,1488,1447,1362,802,696.1 \mathrm{H}-\mathrm{NMR}(400 \mathrm{MHz}, \mathrm{CDCl} 3) \delta=8.77(\mathrm{~s}, 1 \mathrm{H}), 7.83-7.78(\mathrm{~m}, 4 \mathrm{H}), 7.59$ $-7.49(\mathrm{~m}, 6 \mathrm{H}), 7.33(\mathrm{~s}, 1 \mathrm{H}), 7.30(\mathrm{~s}, 1 \mathrm{H}), 7.20-7.17(\mathrm{~m}, 2 \mathrm{H}), 3.23(\mathrm{t}, \mathrm{J}=8.4 \mathrm{~Hz}, 2 \mathrm{H}), 1.88-1.82(\mathrm{~m}, 2 \mathrm{H})$, $1.53-1.46(\mathrm{~m}, 2 \mathrm{H}), 0.99(\mathrm{t}, \mathrm{J}=7.5 \mathrm{~Hz}, 3 \mathrm{H}) .13 \mathrm{C}-\mathrm{NMR}(100 \mathrm{MHz}, \mathrm{CDCl} 3) \delta=151.2,138.7,138.5,138.2$, $135.8,134.5,134.0,129.0,128.9,128.7,128.6,128.3,128.2,127.2,127.0,119.2,117.8,116.5,115.1$, 107.7, 107.3, 34.7, 31.3, 22.9, 14.2. HRMS m/z calcd. for [C29H24N2 + H]+ 401.202, found 401.207.

1-chloro-5,8-diphenylindolizino[6,5,4,3-ija][1,6]naphthyridine (6a): This compound was formed when the metalation step was performed at $-78^{\circ} \mathrm{C}$, (vide supra) and using $\mathrm{C} 2 \mathrm{Cl} 6(1.18 \mathrm{~g})$ as electrophile. After column chromatography (cyclohexane/EtOAc, 90:10), compound 6a was obtained as a yellow solid (182 mg, $37 \%$ ) with a melting point of $238-239^{\circ} \mathrm{C}$. FT-IR v $(\mathrm{cm}-1)=3099,3055,3028,1488,1449$, $1411,1063,794,692.1 \mathrm{H}-\mathrm{NMR}(400 \mathrm{MHz}, \mathrm{CDCl}) \delta=8.58(\mathrm{~s}, 1 \mathrm{H}), 7.84-7.78(\mathrm{~m}, 4 \mathrm{H}), 7.57-7.51(\mathrm{~m}$, $6 \mathrm{H}), 7.49(\mathrm{~s}, 1 \mathrm{H}), 7.33(\mathrm{~s}, 1 \mathrm{H}), 7.27(\mathrm{~s}, 2 \mathrm{H}) .13 \mathrm{C}-\mathrm{NMR}(100 \mathrm{MHz}, \mathrm{CDCl} 3) \delta=138.7,137.8(2 \mathrm{C}), 137.6$, 136.4, 136.3, 135.2, 129.2, 129.1, 129.0, 128.5, 128.4, 127.4, 127.3, 120.7, 118.7, 116.0, 114.8, 109.2, 108.8. HRMS $\mathrm{m} / \mathrm{z}$ calcd. for $[\mathrm{C} 25 \mathrm{H} 15 \mathrm{CIN} 2+\mathrm{H}]+379.100$, found 379.098 .

1-bromo-5,8-diphenylindolizino[6,5,4,3-ija][1,6]naphthyridine (6b): This compound was formed when the metalation step was performed at $-78^{\circ} \mathrm{C}$, (vide supra) and using $\mathrm{CBr} 4(1.65 \mathrm{~g})$ as electrophile. After column chromatography (cyclohexane/EtOAc, 90:10), compound $6 \mathrm{~b}$ was obtained as a yellow solid (181 mg, $33 \%)$ with a melting point of $240-241^{\circ} \mathrm{C}$. FT-IR v $(\mathrm{cm}-1)=3099,3029,1487,1447,1412$, 1382, 1309, 1053, 884, 753, 671. 1H-NMR (400 MHz, CDCl3) $\delta=8.59(\mathrm{~s}, 1 \mathrm{H}), 7.84-7.78(\mathrm{~m}, 4 \mathrm{H}), 7.58$ $-7.52(\mathrm{~m}, 6 \mathrm{H}), 7.51(\mathrm{~s}, 1 \mathrm{H}), 7.34(\mathrm{~s}, 1 \mathrm{H}), 7.29(\mathrm{~d}, \mathrm{~J}=4.3 \mathrm{~Hz}, 1 \mathrm{H}), 7.28(\mathrm{~d}, \mathrm{~J}=4.3 \mathrm{~Hz}, 1 \mathrm{H}) .13 \mathrm{C}-\mathrm{NMR}(100$ $\mathrm{MHz}, \mathrm{CDCl} 3) \delta=138.6,137.9,136.3,135.9,135.2,131.1,129.1,129.0,128.6,128.4,127.4,127.3$, 120.9, 120.8, 116.9, 116.0, 109.2, 108.6. HRMS m/z calcd. for [C25H15BrN2 + H]+ 423.050, found 423.053. 
1-iodo-5,8-diphenylindolizino[6,5,4,3-ija][1,6]naphthyridine (6c): This compound was formed when the metalation step was performed at $-78^{\circ} \mathrm{C}$, (vide supra) and using $12(1.27 \mathrm{~g})$ as electrophile. After column chromatography (cyclohexane/EtOAc, 80:20), compound $6 \mathrm{c}$ was obtained as a yellow solid (263 mg, $43 \%$ ) with a melting point of $210-211^{\circ} \mathrm{C}$. FT-IR $v(\mathrm{~cm}-1)=3029,2917,2848,1487,1445$, $1407,1308,1148,1049,792,763,688.1 \mathrm{H}-\mathrm{NMR}(400 \mathrm{MHz}, \mathrm{CDCl} 3) \delta=8.59(\mathrm{~s}, 1 \mathrm{H}), 7.84-7.77(\mathrm{~m}, 4 \mathrm{H})$, $7.58-7.50(\mathrm{~m}, 6 \mathrm{H}), 7.39(\mathrm{~s}, 1 \mathrm{H}), 7.32(\mathrm{~s}, 1 \mathrm{H}), 7.30(\mathrm{~d}, \mathrm{~J}=4.2 \mathrm{~Hz}, 1 \mathrm{H}), 7.28(\mathrm{~d}, \mathrm{~J}=4.4 \mathrm{~Hz}, 1 \mathrm{H}) .13 \mathrm{C}-\mathrm{NMR}$ $(100 \mathrm{MHz}, \mathrm{CDCl} 3) \delta=136.8,137.9$ (2C), 136.4, 135.5, 134.5, 129.1 (2C), 129.0, 128.6, 128.4, 127.5 (2C), 124.3, 121.0, 120.1, 115.8, 109.3, 109.1, 108.5, HRMS m/z calcd. for [C25H15IN2 + H]+ 471.036, found 471.054.

General procedure for Suzuki cross-coupling of compound 6b.

In a dry $10 \mathrm{ml}$ microwave vial, DMF and water were introduced. Compound $6 \mathrm{~b}(50 \mathrm{mg}, 0.12 \mathrm{mmol}$ ), arylboronic acid (1.3 eq., $0.15 \mathrm{mmol}$ ), Pd(OAc)2 ( $5 \%$ mol., $1.3 \mathrm{mg}, 6 \mu \mathrm{mol})$, PPh3 ( $25 \mathrm{mg}, 96 \mu \mathrm{mol}$ ) and $\mathrm{K} 2 \mathrm{CO} 3$ (49 $\mathrm{mg}, 0.35 \mathrm{mmol}$ ) were introduced and the reaction vessel was sealed with a Teflon cap. Microwave irradiation of $60 \mathrm{~W}$ was used, the temperature being ramped to $110^{\circ} \mathrm{C}$ for 30 minutes. The mixture was then allowed to reach room temperature and the suspended solid was recovered by filtration. The expected compounds were obtained as pure materials after purification on silica flash column chromatography as outlined.

1,5,8-triphenylindolizino[6,5,4,3-ija][1,6]naphthyridine (7a) was prepared using phenylboronic acid (16 mg, $0.15 \mathrm{mmol}$ ). After column chromatography (cyclohexane/EtOAc, 9/1), product 7a was obtained as a yellow solid $(27 \mathrm{mg}, 55 \%)$ with a melting point of $232-233^{\circ} \mathrm{C}$. FT-IR $\vee(\mathrm{cm}-1)=3053,2917,1488$, $1443,1411,1371,1075,1052,1014,776,755,695,674.1 \mathrm{H}-\mathrm{NMR}(400 \mathrm{MHz}, \mathrm{CDCl} 3) \delta=8.89(\mathrm{~s}, 1 \mathrm{H})$, $7.86-7.80(\mathrm{~m}, 4 \mathrm{H}), 7.75-7.73(\mathrm{~m}, 2 \mathrm{H}), 7.57-7.44(\mathrm{~m}, 10 \mathrm{H}), 7.33(\mathrm{~s}, 1 \mathrm{H}), 7.19(\mathrm{~d}, \mathrm{~J}=4 \mathrm{~Hz}, 1 \mathrm{H}), 7.16$ (d, J $=4 \mathrm{~Hz}, 1 \mathrm{H}) .13 \mathrm{C}-\mathrm{NMR}(100 \mathrm{MHz}, \mathrm{CDCl} 3) \delta=148.9,139.8,139.7,138.5,138.3,136.4,134.8,129.2$, 129.0 (2C), 128.8, 128.7, 128.5, 128.4, 128.3, 127.6, 127.3, 120.0, 118.1, 116.5, 116.2, 108.0, 107.7. HRMS m/z calcd. for [C31H2ON2 + H]+ 421.170, found 421.171 .

4-(5,8-diphenylindolizino[6,5,4,3-ija][1,6]naphthyridin-1-yl)benzaldehyde (7b) was prepared using (4formylphenyl)boronic acid (23 mg, $0.15 \mathrm{mmol}$ ). After column chromatography (cyclohexane/EtOAc, $6 / 4)$, product $7 \mathrm{~b}$ was obtained as an orange solid $\left(40 \mathrm{mg}, 76 \%\right.$ ) with a melting point of $252-253^{\circ} \mathrm{C}$. FTIR $v(\mathrm{~cm}-1)=3023,2954,2922,1660,1602,1510,1493,1451,1257,1172,1030,729,597.1 \mathrm{H}-\mathrm{NMR}$ $(400 \mathrm{MHz}, \mathrm{CDCl} 3) \delta=10.11(\mathrm{~s}, 1 \mathrm{H}), 8.93(\mathrm{~s}, 1 \mathrm{H}), 8.06(\mathrm{~s}, 4 \mathrm{H}), 7.84-7.82(\mathrm{~m}, 2 \mathrm{H}), 7.76-7.73(\mathrm{~m}, 2 \mathrm{H})$, $7.59-7.48(\mathrm{~m}, 7 \mathrm{H}), 7.40(\mathrm{~s}, 1 \mathrm{H}), 7.27-7.24(\mathrm{~m}, 2 \mathrm{H}) .13 \mathrm{C}-\mathrm{NMR}(100 \mathrm{MHz}, \mathrm{CDCl} 3) \delta=192.1,146.8$, $145.9,139.8,138.2,138.1,136.3,136.1,135.5,135.4,130.3,129.9,129.1,129.0,128.4$ (2C), 127.8, $127.3,120.5,118.6,116.4,115.4,108.5,108.4$. HRMS m/z calcd. for [C32H2ON2O + H]+ 449.165, found 449.156.

1-(6-chloropyridin-3-yl)-5,8-diphenylindolizino[6,5,4,3-ija]-[1,6] naphthyridine (7c) was prepared using (6-chloropyridin-3-yl)boronic acid (24 $\mathrm{mg}, 0.15 \mathrm{mmol})$. After column chromatography (cyclohexane/EtOAc, 8/2), product 7c was obtained as a yellow solid (25 mg, 46\%) with a melting point of $224-225^{\circ} \mathrm{C}$. FT-IR v (cm-1) = 3055, 2918, 2848, 1580, 1492, 1447, 1415, 1366, 1101, 1007, 804, 745, 699. $1 \mathrm{H}-\mathrm{NMR}(400 \mathrm{MHz}, \mathrm{CDCl}$ ) $\delta 8.93(\mathrm{~d}, \mathrm{~J}=1.7 \mathrm{~Hz}, 1 \mathrm{H}), 8.90(\mathrm{~s}, 1 \mathrm{H}), 8.16(\mathrm{dd}, \mathrm{J}=8.1$ and $2.5 \mathrm{~Hz}, 1 \mathrm{H}$ ), 
$7.83-7.80(\mathrm{~m}, 2 \mathrm{H}), 7.74-7.72(\mathrm{~m}, 2 \mathrm{H}), 7.58-7.49(\mathrm{~m}, 7 \mathrm{H}), 7.47(\mathrm{~s}, 1 \mathrm{H}), 7.37(\mathrm{~s}, 1 \mathrm{H}), 7.27(\mathrm{~d}, \mathrm{~J}=4.3$ $\mathrm{Hz}, 1 \mathrm{H}), 7.25$ (d, J = 4.3 Hz, 1H). 13C-NMR (100 MHz, CDCl3) $\delta=151.1,149.8,143.6,139.9,139.6,138.0$, 136.2, 135.9, 135.5, 134.6, 129.1 (2C, 129.0, 128.4, 127.8, 127.2, 124.6, 118.7, 116.3, 114.7, 108.6, 108.5. HRMS m/z calcd. for [C3OH18CIN3 + H]+ 456.126, found 456.129 .

5-(5,8-diphenylindolizino[6,5,4,3-ija][1,6]naphthyridin-1-yl)thiophene-2-carbaldehyde $\quad$ (7d) was prepared using 5-formyl-2-thienylboronic acid $(24 \mathrm{mg}, 0.15 \mathrm{mmol})$. After column chromatography (cyclohexane/EtOAc, 7/3), product $7 \mathrm{~d}$ was obtained as a red solid $(28 \mathrm{mg}, 52 \%$ ) with a melting point of $242-243^{\circ} \mathrm{C}$. FT-IR $v(\mathrm{~cm}-1)=3024,2915,2837,1658,1591,1572,1510,1422,1292,1255,1223,1171$, 1031, 812, 730. 1H-NMR (400 MHz, CDCl3) $\delta=9.96(\mathrm{~s}, 1 \mathrm{H}), 8.86(\mathrm{~s}, 1 \mathrm{H}), 7.89, \mathrm{~s}, 1 \mathrm{H}), 7.86-7.79(\mathrm{~m}$, $6 \mathrm{H}), 7.60-7.52(\mathrm{~m}, 6 \mathrm{H}), 7.42(\mathrm{~s}, 1 \mathrm{H}), 7.31(\mathrm{~d}, \mathrm{~J}=4.3 \mathrm{~Hz}, 1 \mathrm{H}), 7.30(\mathrm{~d}, \mathrm{~J}=4.3 \mathrm{~Hz}, 1 \mathrm{H}) .13 \mathrm{C}-\mathrm{NMR}(100$ $\mathrm{MHz}, \mathrm{CDCl}) \delta=183.1,153.9,143.4,139.8,139.4,138.2,137.9,136.8,136.3,136.0,135.5,129.2$, $129.1,129.0,128.5$ (2C), 128.4, 128.1, 127.1, 126.5, 120.8, 118.2, 116.8, 115.1, 109.2, 109.0. HRMS $\mathrm{m} / \mathrm{z}$ calcd. for [C3OH18N2OS $+\mathrm{H}]+455.121$, found 455.124 .

General procedure for Sonogashira cross-coupling of compound 6b.

In a dry $10 \mathrm{~mL}$ microwave vial, diethylamine $(0.7 \mathrm{~mL})$ and DMF $(1.3 \mathrm{~mL})$ were introduced. The solvent mixture, cooled at $0^{\circ} \mathrm{C}$ with an ice bath, was then degassed by argon bubbling for 30 minutes. Compound 6b (130 mg, $0.31 \mathrm{mmol}$ ), PdCl2(PPh3)2 (11 mg, $15 \mu \mathrm{mol})$, Cul (3 mg, $15 \mu \mathrm{mol}$ ), triphenylphosphine $(13 \mathrm{mg}, 50 \mu \mathrm{mol})$ and alkynes (1.1 eq., $0.34 \mathrm{mmol})$ were introduced and the reaction vessel was sealed with a Teflon cap. Microwave irradiation of $60 \mathrm{~W}$ was used, the temperature being ramped to $120^{\circ} \mathrm{C}$, temperature at which the reaction was heated for 25 minutes. The mixture was then allowed to reach room temperature, filtered through a pad of Celite, washed with dichloromethane and concentrated to dryness under reduced pressure. The residue was taken up in ethyl acetate $(35 \mathrm{~mL})$. The organic layer was washed with water $(2 \times 20 \mathrm{~mL})$ and sat. $\mathrm{NaCl}(20 \mathrm{~mL})$, dried with $\mathrm{MgSO} 4$, filtered, and concentrated under reduced pressure. The expected compounds were obtained as pure materials after purification on silica flash column chromatography as outlined.

5,8-diphenyl-1-(phenylethynyl)indolizino[6,5,4,3-ija][1,6]naphthyridine (8a) was prepared with phenylacetylene $(38 \mu \mathrm{L}, 0.34 \mathrm{mmol}$ ). After column chromatography (cyclohexane/EtOAc, 9/1) product 8 a was obtained as an orange solid $(104 \mathrm{mg} ; 76 \%)$ with a melting point of $171-172^{\circ} \mathrm{C}$. FT-IR v $(\mathrm{cm}-1)=$ $3054,1540,1488,1447,1370,1359,1083,799,757,690.1 \mathrm{H}-\mathrm{NMR}(400 \mathrm{MHz}, \mathrm{CDCl} 3) \delta=8.81(\mathrm{~s}, 1 \mathrm{H})$, $7.86-7.79(\mathrm{~m}, 4 \mathrm{H}), 7.71(\mathrm{~s}, 1 \mathrm{H}), 7.69-7.66(\mathrm{~m}, 2 \mathrm{H}), 7.59-7.50(\mathrm{~m}, 6 \mathrm{H}), 7.39-7.36(\mathrm{~m}, 4 \mathrm{H}), 7.27(\mathrm{~d}$, $\mathrm{J}=4.3 \mathrm{~Hz}, 1 \mathrm{H}), 7.26(\mathrm{~d}, \mathrm{~J}=4.3 \mathrm{~Hz}, 1 \mathrm{H}) . \mathrm{RMN} 13 \mathrm{C}(\mathrm{CDCl} 3,100 \mathrm{MHz}) \delta=140.2,138.2,138.0,135.7,135.3$, 134.9, 132.1, 131.1, 129.1 (2C), 128.9, 128.8, 128.6, 128.5, 127.5, 127.3, 123.0, 122.2, 120.2, 116.5, 116.4, 109.0, 108.7, 94.1, 87.7. HRMS m/z calcd. for [C33H2ON2 + H]+ 445.170, found 445.167.

$\mathrm{N}, \mathrm{N}$-dibutyl-4-((5,8-diphenylindolizino[6,5,4,3-ija][1,6]naphthyridin-1-yl)ethynyl)aniline $\quad$ (8b) was prepared with $\mathrm{N}, \mathrm{N}$-dibutyl-4-ethynylaniline $(78 \mathrm{mg}, 0.34 \mathrm{mmol})$. After column chromatography (cyclohexane/EtOAc, 8/2) product $8 \mathrm{~b}$ was obtained as a brown oil $(95 \mathrm{mg} ; 54 \%$ ) with a melting point of $214-215^{\circ} \mathrm{C}$. FT-IR v $(\mathrm{cm}-1)=2955,2928,1602,1519,1448,1367,1198,813,774$. 1H-NMR $(400 \mathrm{MHz}$, $\mathrm{CDCl} 3) \delta=8.81(\mathrm{~s}, 1 \mathrm{H}), 7.87-7.80(\mathrm{~m}, 4 \mathrm{H}), 7.73(\mathrm{~s}, 1 \mathrm{H}), 7.60-7.50(\mathrm{~m}, 8 \mathrm{H}), 7.35(\mathrm{~s}, 1 \mathrm{H}), 7.24(\mathrm{~s}, 2 \mathrm{H})$, $6.61(\mathrm{~d}, \mathrm{~J}=7.7 \mathrm{~Hz}, 2 \mathrm{H}), 3.30(\mathrm{t}, \mathrm{J}=6.8 \mathrm{~Hz}, 4 \mathrm{H}), 1.61-1.57(\mathrm{~m}, 4 \mathrm{H}), 1.40-1.34(\mathrm{~m}, 4 \mathrm{H}), 0.97(\mathrm{t}, \mathrm{J}=5.7$ 
$\mathrm{Hz}, 6 \mathrm{H}) . \mathrm{RMN} 13 \mathrm{C}(\mathrm{CDCl} 3,100 \mathrm{MHz}) \delta=148.5,140.1,138.4,138.2,135.3,135.2,134.8,133.6,132.3$, $132.2,129.1$ (2C), 128.9, 128.8, 128.7, 128.6, 128.5, 127.5 (2C), 121.5, 119.7, 116.9, 116.7, 111.4, $108.5,108.4,108.2,106.1,95.8,85.8$. HRMS m/z calcd. for [C41H37N3 + H]+ 572.306, found 572.305.

1,3-dibromo-5,8-diphenylindolizino[6,5,4,3-ija][1,6]naphthyridine (9). To a solution of compound $6 \mathrm{~b}$ (131 $\mathrm{mg}, 0.31 \mathrm{mmol})$ in anhydrous DMF $(10 \mathrm{~mL})$ was added NBS $(58 \mathrm{mg}, 0.32 \mathrm{mmol}$ ) and the reaction mixture was stirred at room temperature for $18 \mathrm{~h}$. Then, the reaction mixture was poured into ice-cold water $(10 \mathrm{~mL})$. The solid was separated by filtration and washed with cold water, diethylether, cyclohexane and finally with diethylether. The residue was suspended in dichloromethane in presence of $\mathrm{SiO} 2$, and the volatiles were removed under reduced pressure to get the crude product deposited onto silica, which was then purified on silica gel chromatography using a mixture of $\mathrm{CH} 2 \mathrm{Cl} 2 /$ cyclohexane (1/1). Product 9 was obtained as a yellow solid $(90 \mathrm{mg}, 58 \%)$ with a melting point up to $260^{\circ} \mathrm{C}$. FT-IR v (cm-1) $=3129,2921,1484,1447,1420,1376,1364,1063,843,795,754,709.1 \mathrm{H}-$ NMR $(400 \mathrm{MHz}, \mathrm{CDCl} 3) \delta=7.85-7.82(\mathrm{~m}, 4 \mathrm{H}), 7.59-7.55(\mathrm{~m}, 6 \mathrm{H}), 7.54(\mathrm{~s}, 2 \mathrm{H}), 7.37(\mathrm{~s}, 2 \mathrm{H}) .13 \mathrm{C}-\mathrm{NMR}$ $(100 \mathrm{MHz}, \mathrm{CDCl} 3) \delta=137.7,136.3,136.0,129.3,129.2,128.7,127.9,127.7,120.9,116.9,109.8$. HRMS $\mathrm{m} / \mathrm{z}$ calcd. for $[\mathrm{C} 25 \mathrm{H} 14 \mathrm{Br} 2 \mathrm{~N} 2+\mathrm{H}]+500.960$, found 500.969 .

1,3,5,8-tetraphenylindolizino[6,5,4,3-ija][1,6]naphthyridine (10a). In a dry $30 \mathrm{ml}$ microwave vial, DMF $(4 \mathrm{~mL})$ and water $(2 \mathrm{~mL})$ were introduced and the solvent mixture was degassed by argon bubbling for 30 minutes. Compound 9 ( $50 \mathrm{mg}, 99.6 \mu \mathrm{mol})$, phenylboroonic acid ( $39 \mathrm{mg}, 0.26 \mathrm{mmol}), \mathrm{Pd}(\mathrm{OAc}) 2$ (3.3 $\mathrm{mg}, 15 \mu \mathrm{mol}), \mathrm{PPh} 3(31 \mathrm{mg}, 0.12 \mathrm{mmol}$ ) and $\mathrm{K} 2 \mathrm{CO} 3(55 \mathrm{mg}, 0.40 \mathrm{mmol}$ ) were introduced and the reaction vessel was sealed with a Teflon cap. Microwave irradiation of $60 \mathrm{~W}$ was used, the temperature being ramped to $110^{\circ} \mathrm{C}$ for 30 minutes. The reaction mixture was then allowed to reach room temperature, poured into ice-cold water and the suspended yellow solid was recovered by filtration and washed with diethylether to remove PPh3. The crude solid was deposited on silica (evaporation of a dichloromethane solution in presence of silica) and was purified on silica gel chromatography (cyclohexane/EtOAc, 97.5/2.5). Product 10a was obtained as a yellow solid (39 mg, 78\%) with a melting point up to $260^{\circ} \mathrm{C}$. FT-IR $v(\mathrm{~cm}-1)=2921,2850,1484,1444,1409,1374,1313,1055,1014,871,781$, $718,699,669.1 \mathrm{H}-\mathrm{NMR}(400 \mathrm{MHz}, \mathrm{CDCl}) \delta=7.90(\mathrm{~d}, \mathrm{~J}=6.8 \mathrm{~Hz}, 4 \mathrm{H}), 7.76(\mathrm{~d}, \mathrm{~J}=7.7 \mathrm{~Hz}, 4 \mathrm{H}), 7.60(\mathrm{~s}$, $2 \mathrm{H}), 7.55-7.44(\mathrm{~m}, 12 \mathrm{H}), 7.18(\mathrm{~s}, 2 \mathrm{H})$. HRMS m/z calcd. for [C37H24N2 + H]+ 497.2018, found 197.2015.

5,8-diphenyl-1,3-bis(phenylethynyl)indolizino[6,5,4,3ija][1,6]naphthyridine (10b). In a dry $10 \mathrm{~mL}$ microwave vial, diethylamine $(0.6 \mathrm{~mL})$ and DMF $(1.4 \mathrm{~mL})$ were introduced. The solvent mixture, cooled at $0^{\circ} \mathrm{C}$ with an ice bath, was then degassed by argon bubbling for 30 minutes. Compound $9(50 \mathrm{mg}$, $99.6 \mu \mathrm{mol}), \mathrm{PdCl} 2(\mathrm{PPh} 3) 2(14 \mathrm{mg}, 20 \mu \mathrm{mol})$, Cul $(4 \mathrm{mg}, 20 \mu \mathrm{mol})$, triphenylphosphine (11 mg, $40 \mu \mathrm{mol})$ and phenylacetylene $(28 \mu \mathrm{L}, 0.25 \mathrm{mmol})$ were introduced and the reaction vessel was sealed with a Teflon cap. Microwave irradiation of $60 \mathrm{~W}$ was used, the temperature being ramped to $120^{\circ} \mathrm{C}$, temperature at which the reaction was heated for 30 minutes. The mixture was then allowed to reach room temperature, cooled at $0^{\circ} \mathrm{C}$ and diluted with cold diethyl ether $(20 \mathrm{~mL})$. The suspended red solid was separated by filtration and washed with cold diethyl ether. The solid was then solubilized in $\mathrm{CHCl} 3$ $(50 \mathrm{~mL})$. The organic solution was washed with water $(2 \times 50 \mathrm{~mL})$, dried with MgSO4, filtered, and concentrated under reduced pressure. Product $10 \mathrm{~b}$ was obtained as a red solid (46 mg; $85 \%$ ) with a melting point up to $260^{\circ} \mathrm{C}$. FT-IR $\vee(\mathrm{cm}-1)=3055,2920,1536,1489,1360,1102,871,799,775,757$, 704, 688. $1 \mathrm{H}-\mathrm{NMR}(400 \mathrm{MHz}, \mathrm{CDCl}) \delta=7.89-7.87(\mathrm{~m}, 4 \mathrm{H}), 7.85(\mathrm{~s}, 2 \mathrm{H}), 7.71-7.69(\mathrm{~m}, 4 \mathrm{H}), 7.63-$ 
$7.53(\mathrm{~m}, 6 \mathrm{H}), 7.41-7.39(\mathrm{~m}, 6 \mathrm{H}), 7.39$ (s, 2H). 13C-NMR (100 MHz, CDCl3) $\delta=138.1,136.0,134.8$, $132.2,131.5,129.2,129.1,129.0,128.7,128.6,127.9,122.9,121.9,116.9,109.7,94.0,87.3$. HRMS m/z calcd. for [C41H24N2 + H]+545.2018, found 545.2020 .

\section{Acknowledgements}

This work was financially supported by the University of Lorraine and the CNRS. The authors would like to thank V. Vaillant and Dr. Sandrine Rup for recording NMR spectra and Dr. F. Dupire for mass spectrometry analyses.

Keywords: Azaullazine $\bullet$ Regioselective $\bullet$ Functionalization $\bullet$ Substitution $\bullet$ Cross-coupling

[1] H. Xin, B. Hou, X. Gao, Acc. Chem. Res. 2021, 54, 1737-1753

[2] M. Stepien, E. Gonka, M. Zyla, N. Sprutta, Chem. Rev. 2017, 117, 3479-3716.

[3] H. Zhang, Z.-E. Chen, H.-Rong. Tian, Sol. Energy 2020, 198, 239-246.

[4] Y. Ren, J. Liu, A. Zheng, X. Dong, Peng. Wang, Adv. Sci. Weinh. Ger. 2017, 4, n/a.

[5] Z. Yao, M. Zhang, R. Li, L. Yang, Y. Qiao, Peng. Wang, Angew. Chem. Int. Ed. 2015, 54, 59945998.

[6] J. H. Delcamp, A. Yella, T. W. Holcombe, M. K. Nazeeruddin, M. Grätzel, Angew. Chem. Int. Ed. 2013, 52, 376-380.

[7] D. Miao, C. Aumaitre, J.-F. Morin, J. Mater. Chem. C 2019, 7, 3015-3024.

[8] R. Ozdemir, S. Park, I. Deneme, Y. Park, Y. Zorlu, H. A. Alidagi, K. Harmandar, C. Kim, Hakan. Usta, Org. Chem. Front. 2018, 5, 2912-2924.

[9] F. Zhou, S. Liu, B. D. Santarsiero, D. J. Wink, D. Boudinet, A. Facchetti, Tom. Driver, Chem. - Eur. J. 2017, 23, 12542-12549.

[10] R.-Q. Lu, Y.-N. Zhou, X.-Y. Yan, K. Shi, Y.-Q. Zheng, M. Luo, X.-C. Wang, J. Pei, H. Xia, L. Zoppi, K. K. Baldridge, J. S. Siegel, X.-Yu. Cao, Chem. Commun. Camb. U. K. 2015, 51, 1681-1684.

[11] H. Balli, M. Zeller, Helv. Chim. Acta 1983, 66, 2135-2139.

[12] K. Kanno, Y. Liu, A. lesato, K. Nakajima, T. Takahashi, Org. Lett. 2005, 7, 5453-5456.

[13] J. Zhou, W. Yang, B. Wang, H. Ren, Angew. Chem. Int. Ed. 2012, 51, 12293-12297.

[14] A. Das, I. Ghosh, B. König, Chem Commun 2016, 52, 8695-8698.

[15] D. Wan, X. Li, R. Jiang, B. Feng, J. Lan, R. Wang, J. You, Org. Lett. 2016, 18, 2876-2879.

[16] S. Ito, Y. Tokimaru, K. Nozaki, Chem Commun 2015, 51, 221-224.

[17] R. Berger, M. Wagner, X. Feng, K. Müllen, Chem Sci 2015, 6, 436-441.

[18] D. Wang, Y. Liu, L. Wang, H. Cheng, Y. Zhang, G. Gao, Chin. Chem. Lett. 2020, S1001841720305623.

[19] S. Boldt, S. Parpart, A. Villinger, P. Ehlers, P. Langer, Angew. Chem. Int. Ed. 2017, 56, 45754578. 
[20] P. Pierrat, S. Hesse, C. Cebrián, P. C. Gros, Org Biomol Chem 2017, 15, 8568-8575.

[21] D. Bandyopadhyay, S. Mukherjee, B. K. Banik, Molecules 2010, 15, 2520-2525.

[22] P.C. Gros, Y. Fort, Eur. J. Org. Chem. 2002, 3375-3383.

[23] C. J. Woltermann, P. C. Gros, PharmaChem 2007, 6, 20-22.

[24] P.C. Gros, S. Choppin, Y. Fort, J. Org. Chem. 2003, 68, 2243-2247.

[25] T. Kaminski, P.C. Gros, Y. Fort, Eur. J. Org. Chem. 2003, 3855-3860.

[26] M. Parmentier, P.C. Gros, Y. Fort, Tetrahedron 2005, 61, 3261-3269.

[27] D. Martineau, P.C. Gros, Y. Fort, J. Org. Chem. 2004, 69, 7914-7918.

[28] G. M. Sheldrick, Acta Crystallogr. A 2008, 64, 112-122. 